\title{
Social Support To Women With Breast Cancer Undergoing Treatment
}

\author{
Luthfiyyah Khanuun', Sri Nabawiyati Nurul Makiyah²
}

1 Master of Nursing, Universitas Muhammadiyah Yogyakarta

2 School of Medicine, Faculty of Medicine and Health Sciences Universitas Muhammadiyah Yogyakarta

\begin{tabular}{l}
\multicolumn{1}{c}{ Article Info } \\
\hline Article History: \\
Submitted: July $14^{\text {th }}, 2021$ \\
Accepted: August $30^{\text {th }}, 2021$ \\
Published: August $31^{\text {st }}, 2021$ \\
Keywords: \\
Breast Cancer; Social \\
Support; Oncological \\
Treatment; Qualitative \\
Research
\end{tabular}

\section{PENDAHULUAN}

Kanker payudara adalah penyakit dimana sel-sel pada jaringan payudara membelah secara tidak normal, tidak terkendali, dan biasanya menimbulkan benjolan atau massa [1]. Kanker payudara adalah jenis kanker yang paling umum pada wanita dan merupakan pembunuh nomor satu didunia [2]. Jumlah penderita kanker payudara meningkat setiap tahunnya.

\section{Berdasarkan data Global Cancer Observatory, 2020 dari World Health Organization (WHO) menunjukkan kasus terbaru kanker payudara secara global berada pada peringkat pertama sebanyak 2.261.419 kasus (11,7\%). Asia memiliki \\ 2.261 .419 kasus $(11,7 \%)$. Asia memiliki}

\section{Abstract}

Breast cancer treatment will have an impact on quality of life and social support that leads to interpersonal women with breast cancer. This study aims to explore and synthesize the scientific literature on the social support to women with breast cancer who underwent treatment in the and support", "Oncological treatment", "Qualitative Research". The search article was carried out in accordance with the guideline of PRISMA. The findings in study contained 4 main themes from 6 articles. Research findings inction support, emotional response support, support for finding and support for meeting, unmet needs. This support began to be felt since the patient was first diagnosed with breast cancer. This is very real and accepted support that has a positive impact on the lives of women with breast cancer.

Corresponding author:

Luthfiyyah Khanuun

luthfiyyahkhanuun68@gmail.com

Media Keperawatan Indonesia, Vol 4 No 3, August 2021

e-ISSN: 2615-1669

ISSN: 2722-2802

DOI: $\underline{10.26714 / \mathrm{mki} \cdot 4.3 .2021 .247-255}$

populasi kasus kanker payudara tertinggi selama lima tahun berturut-turut. Indonesia menduduki peringkat pertama pada tahun 2020 sebanyak 65.858 kasus baru $(16,6 \%)$ $[3,4]$. Masalah kanker payudara sudah menjadi masalah yang sangat serius dan perlu mendapatkan perhatian lebih bagi semua pihak.

Kanker payudara merupakan masalah kesehatan yang sangat kompleks dan perlu ditangani secara menyeluruh. Penatalaksanaan kanker payudara yang umumnya menjadi pertimbangan baik dalam pengobatan, yaitu tindakan mastektomi [5]. Mastektomi adalah prosedur invasif yang mengangkat seluruh atau sebagian payudara yang disebabkan 
oleh kanker payudara [6]. Beberapa wanita hanya memerlukan tindakan kuadrantektomi, yaitu pengangkatan seperempat payudara, atau lumpektomi yang hanya mengangkat tumor atau area kecil di sekitarnya. Dalam kasus yang lebih lanjut, radioterapi dan kemoterapi adalah metode pengobatan yang diindikasikan tergantung pada berbagai faktor seperti usia, lokasi tumor, ketersediaan keuangan, analisis mamografi, dan cara pasien merawat payudara yang terkena [7].

Selain pengobatan yang harus dilakukan, wanita penderita kanker payudara harus mempertimbangkan efek penyakit seperti penolakan, ketakutan akan kematian, stigma, kekambuhan, efek pengobatan, ketidakpastian masa depan, dan lain-lain yang harus dinilai dari kualitas hidup. Pasien kanker payudara memiliki banyak kebutuhan termasuk perlunya strategi menghadapi stres yang dialami selama dan setelah perawatan [8]. Dukungan sosial sangat dibutuhkan dalam kondisi ini, tidak hanya terkait dengan tindakan yang dialami.

Dukungan sosial merupakan strategi dalam mengurangi efek stres yang dialami pasien kanker payudara. Interaksi dengan orang lain dapat mengubah persepsi individu dan akan mengurangi potensi munculnya tekanan [9-11]. Dukungan sosial adalah suatu struktur yang terdiri dari keluarga, pasangan, teman, dan individu lain yang terhubung dan saling memberikan dukungan. Hal ini menjadikan dukungan sosial sebagai kunci keamanan emosional bagi setiap individu, karena setiap individu perlu menjadi bagian dari keluarga atau kelompok teman [9]. Oleh karena itu, perlu memperdalam dukungan sosial yang diberikan kepada wanita penderita kanker payudara yang sedang menjalani perawatan di rumah sakit.

\section{METODE}

Artikel-artikel yang termasuk dalam review adalah artikel tentang pengalaman wanita pasca mastektomi yang menerima dukungan sosial. Review ini akan membahas artikel-artikel yang menggunakan metode kualitatif dengan berbagai pendekatan, seperti deskriptif, fenomenologis, laporan kasus, etnografi, dan grounded theory. Artikel yang digunakan adalah penelitian studi tentang aspek dukungan sosial yang diberikan oleh keluarga. Aspek dukungan sosial dari tinjauan ini adalah pengalaman dukungan yang diterima wanita dengan kanker payudara setelah operasi. Diskusi melibatkan pengalaman fisik dan emosional aspek dukungan sosial yang dialami langsung oleh wanita pasca mastektomi. Tinjauan ini tidak terbatas pada wilayah atau negara tertentu dan dilakukan di pusat kesehatan atau di komunitas.

\section{Metode pencarian literatur}

Pencarian literatur dalam penelitian ini menggunakan empat database: PubMed, EBSCO, Science Direct, dan Google Scholar. Kata kunci utama yang digunakan dalam ulasan ini adalah "Social Support" AND "Women" AND "Breast Cancer" AND "Oncological Treatment" AND "Qualitative Research OR Qualitative OR Ethnography”. Periode publikasi terbatas untuk meliput artikel yang diterbitkan dari tahun 2015 hingga 2021. Penelitian ini mengkaji kasus kanker payudara yang menjalani mastektomi dalam lima tahun terakhir untuk melihat dukungan sosial yang telah diberikan oleh keluarga terutama selama masa pengobatan. Saat ini dukungan yang diberikan semakin dipengaruhi oleh nilainilai sosial, sikap, dan budaya dalam keluarga dan masyarakat. Artikel hanya dalam bahasa Inggris, teks lengkap, artikel di mana wanita dengan kanker payudara menerima metode kualitatif, dan topik yang terkait dengan dukungan sosial untuk wanita dengan kanker payudara. Kriteria eksklusi artikel ini meliputi artikel dengan metode penelitian yang tidak lengkap, artikel yang tidak tersedia teks lengkapnya, dan artikel yang tidak membahas dukungan 
sosial pada wanita penderita kanker payudara.

Tinjauan ini menggunakan lima langkah dalam literatur pencarian. Langkah pertama adalah perumusan, dalam langkah ini mengembangkan kata kunci dengan mencoba berbagai kata kunci untuk menjawab tujuan penelitian. Tahap kedua adalah identifikasi, pada tahap ini perlu dilakukan pencarian dengan menggunakan kata kunci yang ditentukan dan membatasi bahasa yang digunakan dan teks lengkap. Sehingga pada tahap ini ditemukan 331 artikel. Langkah ketiga adalah pemilihan artikel, dimana artikel yang ditemukan diseleksi berdasarkan judul dan abstrak. Sehingga pada tahap ini ditemukan 50 artikel yang dimasukkan berdasarkan judul dan abstrak. Langkah keempat adalah pemetaan data, dimana artikel yang sudah terkumpul dipanggil kembali oleh peneliti dan memilah artikel yang mendukung dan yang tidak mendukung review. Hasil penyaringan artikel dari grafik pada tahap ini adalah 15 artikel. Tahap terakhir pada langkah kelima adalah penilaian penting artikel menggunakan alat dari Joanna Briggs Institution (JBI) untuk dapat melihat dan menilai kualitas artikel. Hasil akhir yang diperoleh pada tahap ini adalah 6 artikel (Gambar 1).

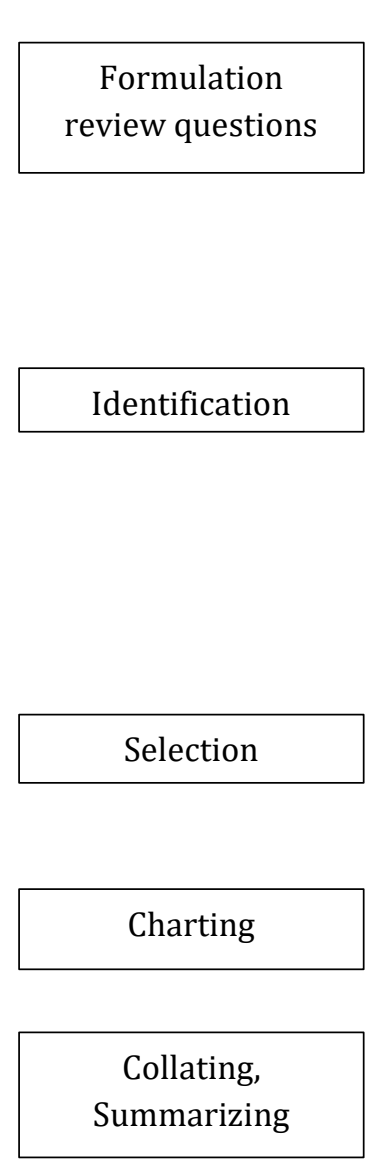

Key term: Social support, Women, Breast cancer, Oncological treatment,

Qualitative research

\begin{tabular}{|c|c|c|c|}
\hline \multicolumn{4}{|c|}{331 result from word search from the computer-based search } \\
\hline PubMed & EBSCO & Science Direct & Google Scholar \\
\hline 212 & 48 & 65 & 6 \\
\hline
\end{tabular}

50 result from the suitability of the title with the abstract screening technique and the title manually

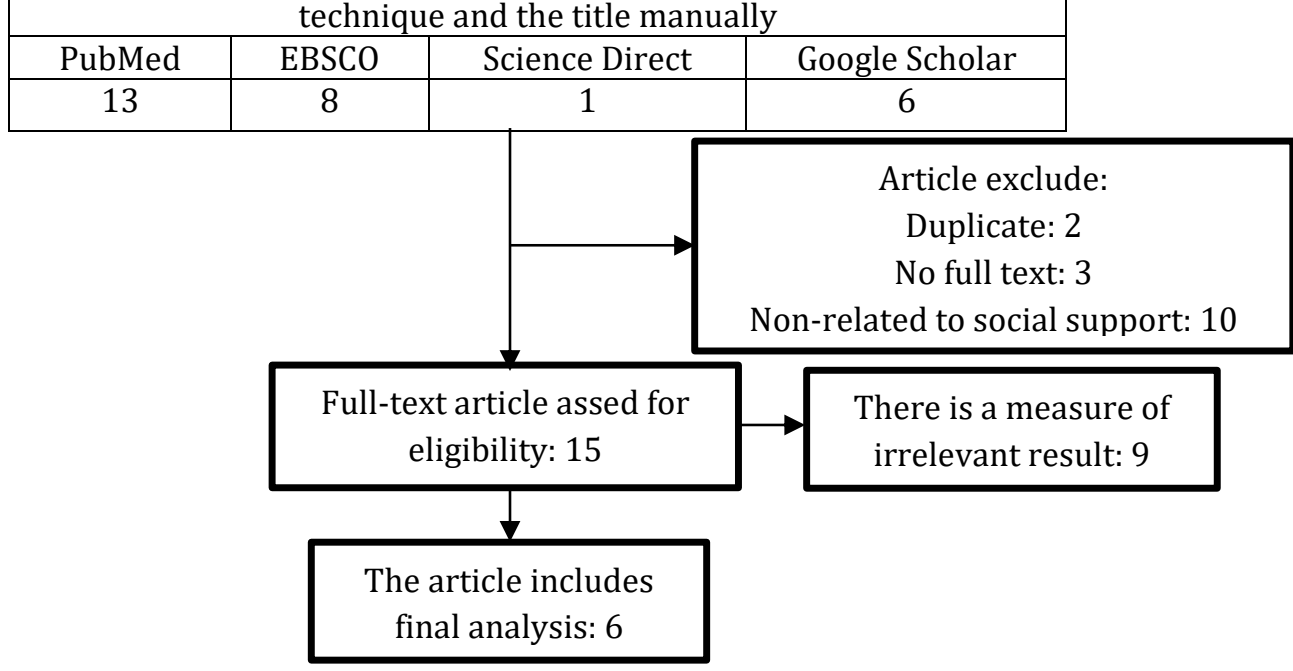

Gambar 1

PRISMA flow diagram

\section{Analisis Data}

Tinjauan ini menggunakan wawasan analisis tematik dengan pola makna (tema) dalam keseluruhan kumpulan data. Data yang diperoleh akan dikelompokkan, dikategorikan, dan diringkas dengan analisis data. Analisis tematik adalah metode analisis yang digunakan untuk mengidentifikasi dan mengatur secara sistematis dan kesimpulan yang sistematis untuk menjawab masalah penelitian dalam 
tinjauan ini. Dalam analisis tematik dilakukan 5 langkah (Gambar 2).

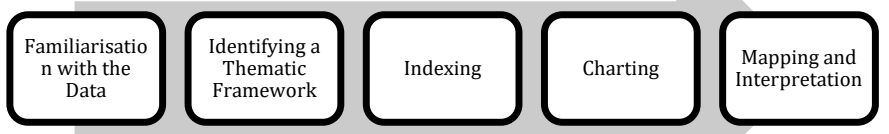

Gambar 2

Langkah-langkah analisis

Langkah pertama adalah pengenalan data, langkah ini adalah meninjau dan mencatat tema yang berulang di seluruh artikel. Langkah kedua adalah mengidentifikasi kerangka tematik. Langkah ini, penulis membuat kerangka kerja yang diadaptasi dari tema-tema yang muncul. Kerangka kerja ini menghasilkan daftar rinci tentang dukungan sosial yang diterima oleh wanita kanker payudara yang menerima terapi. Langkah ketiga adalah pengindeksan, pada langkah ini, dua penulis meninjau informasi secara mandiri dan mencari tema yang sesuai dengan kerangka kerja. Langkah ini jika muncul tema tambahan yang dikoreksi sesuai kesepakatan penulis. Pengkodean didasarkan pada tema-tema yang telah diidentifikasi dalam data dengan kerangka tema. Satu artikel dapat diindeks menggunakan satu atau lebih dari satu kode. Langkah keempat adalah membuat grafik, langkah ini mengurutkan data yang diperoleh berdasarkan tema dan menyajikannya dalam bentuk tabel analisis.
Tabel tersebut menjelaskan studi dan tema, sehingga memudahkan untuk membandingkan temuan studi di berbagai tema dan subtema. Langkah kelima adalah pemetaan dan interpretasi. Pada langkah ini, data disajikan dalam bentuk grafik untuk memudahkan dalam mendefinisikan konsep. Kemudian data tersebut dideskripsikan secara rinci termasuk hubungan antara tema-tema yang mengarah pada tujuan penelitian. Hal ini dapat memberikan pemahaman yang lebih baik tentang pengalaman dukungan sosial yang diterima wanita dengan kanker payudara selama perawatan dari perspektif individu dan lingkungan. Setelah menemukan tema, tinjau kembali tematema yang relevan dengan melihat kesamaan pada masing-masing tema.

\section{HASIL}

Sebanyak 6 artikel yang diulas, membahas dukungan yang diberikan dan dirasakan kepada wanita penderita kanker payudara yang sedang menjalani pengobatan [9,10,12-15]. Setelah meninjau artikel, penulis mengidentifikasi dukungan sosial yang diberikan kepada pasien kanker payudara yang menjalani perawatan. Berdasarkan 6 artikel yang dianalisis, menghasilkan 4 tema utama. Tema yang dihasilkan mewakili dukungan sosial yang diberikan kepada wanita penderita kanker payudara selama perawatan, seperti yang ditunjukkan pada gambar 3. Tema-tema yang ditemukan memiliki hubungan antara satu tema dengan tema lainnya.

Tabel 1

Karakteristik literatur yang disertakan

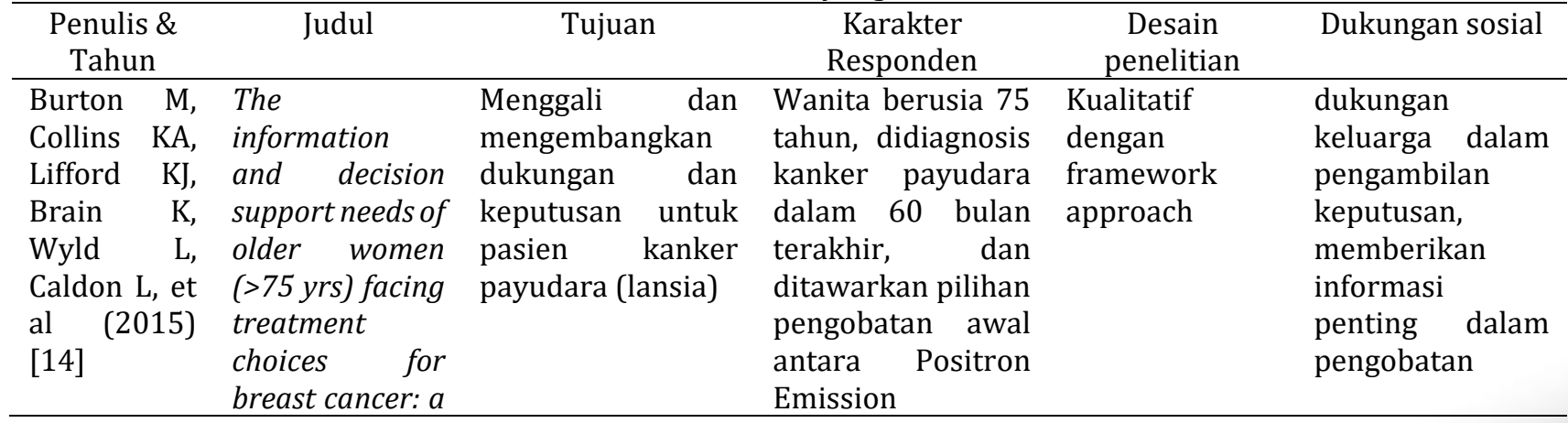




\begin{tabular}{|c|c|c|c|c|c|}
\hline $\begin{array}{l}\text { Penulis \& } \\
\text { Tahun }\end{array}$ & Judul & Tujuan & $\begin{array}{c}\text { Karakter } \\
\text { Responden }\end{array}$ & $\begin{array}{c}\text { Desain } \\
\text { penelitian } \\
\end{array}$ & Dukungan sosial \\
\hline & $\begin{array}{l}\text { qualitative } \\
\text { study }\end{array}$ & & $\begin{array}{l}\text { Tomography atau } \\
\text { pembedahan }\end{array}$ & & \\
\hline $\begin{array}{lr}\text { Tompkins C, } \\
\text { Scanlon K, } \\
\text { Scott } & \text { E, } \\
\text { Ream } & \text { E, } \\
\text { Harding } & \text { S, } \\
\text { Armes J } \\
(2016)[10]\end{array}$ & $\begin{array}{l}\text { Survivorship } \\
\text { care and } \\
\text { support } \\
\text { following } \\
\text { treatment for } \\
\text { breast cancer: a } \\
\text { multi-ethnic } \\
\text { comparative } \\
\text { qualitative } \\
\text { study of } \\
\text { women's } \\
\text { experiences }\end{array}$ & $\begin{array}{l}\text { Menggali } \\
\text { pengalaman } \\
\text { wanita penderita } \\
\text { kanker payudara } \\
\text { dari berbagai } \\
\text { dukungan sosial } \\
\text { dan budaya untuk } \\
\text { memastikan model } \\
\text { perawatan baru } \\
\text { dalam memenuhi } \\
\text { kebutuhan } \\
\text { mereka. }\end{array}$ & $\begin{array}{l}\text { Wanita yang telah } \\
\text { menyelesaikan } \\
\text { rawat inap untuk } \\
\text { kanker payudara } \\
\text { invasif primer } \\
\text { dalam } 12 \text { bulan } \\
\text { sebelumnya, } \\
\text { berusia > } 30 \text { tahun } \\
\text { dan berbicara } \\
\text { bahasa Inggris. }\end{array}$ & $\begin{array}{l}\text { Kualitatif } \\
\text { dengan studi } \\
\text { fenomenologis }\end{array}$ & $\begin{array}{l}\text { Dukungan } \\
\text { emosional yang } \\
\text { diberikan, } \\
\text { informasi yang } \\
\text { ditemukan untuk } \\
\text { tindak lanjut } \\
\text { kesehatan pasien } \\
\text { dalam memenuhi } \\
\text { semua } \\
\text { kebutuhannya }\end{array}$ \\
\hline $\begin{array}{l}\text { Paladino AJ, } \\
\text { Anderson } \\
\text { JN, Graff JC, } \\
\text { Krukowski } \\
\text { RA, Blue R, } \\
\text { Jones TN, et } \\
\text { al. (2019) } \\
\text { [13] }\end{array}$ & $\begin{array}{l}\text { A Qualitative } \\
\text { Exploration of } \\
\text { Race-based } \\
\text { Differences in } \\
\text { Social Support } \\
\text { Needs ofDiverse } \\
\text { Women with } \\
\text { Breast Cancer } \\
\text { on Adjuvant } \\
\text { Therapy }\end{array}$ & $\begin{array}{l}\text { Menjelajahi } \\
\text { kebutuhan } \\
\text { dukungan sosial } \\
\text { wanita dengan } \\
\text { kanker payudara } \\
\text { yang hitam dan } \\
\text { putih, agen } \\
\text { endokrin adjuvant } \\
\text { reseptor hormon } \\
\text { positif. }\end{array}$ & $\begin{array}{l}\text { Wanita berusia } 18 \\
\text { tahun ke atas } \\
\text { didiagnosis } \\
\text { dengan kanker } \\
\text { payudara } \\
\text { awal stadium } \\
\text { hormon-reseptor- } \\
\text { positif (I-III) } \\
\text { diresepkan terapi } \\
\text { endokrin adjuvant } \\
\text { (tamoxifen atau } \\
\text { aromatase } \\
\text { inhibitor). }\end{array}$ & $\begin{array}{l}\text { Metode } \\
\text { kualitatif } \\
\text { dengan } 4 \text { kali } \\
\text { Focus group } \\
\text { discussion }\end{array}$ & $\begin{array}{l}\text { Dukungan sosial, } \\
\text { dukungan } \\
\text { informasi, dan } \\
\text { dukungan } \\
\text { emosional dalam } \\
\text { memenuhi } \\
\text { kebutuhan } \\
\text { pasien dari } \\
\text { teman, keluarga, } \\
\text { dan antar pasien }\end{array}$ \\
\hline $\begin{array}{l}\text { Adam A, } \\
\text { Koranteng } \\
\text { F. } \quad(2020) \\
{[15]}\end{array}$ & $\begin{array}{l}\text { Availability, } \\
\text { accessibility, } \\
\text { and impact of } \\
\text { social support } \\
\text { on breast } \\
\text { cancer } \\
\text { treatment } \\
\text { among breast } \\
\text { cancer patients } \\
\text { in Kumasi, } \\
\text { Ghana: A } \\
\text { qualitative } \\
\text { study }\end{array}$ & $\begin{array}{l}\text { Kaji ketersediaan } \\
\text { dukungan sosial } \\
\text { untuk pasien } \\
\text { kanker payudara } \\
\text { yang menerima } \\
\text { pengobatan } \\
\text { kanker payudara }\end{array}$ & $\begin{array}{l}\text { Semua wanita } \\
\text { yang menerima } \\
\text { pengobatan } \\
\text { kanker payudara, } \\
\text { berusia minimal } \\
18 \text { tahun, dan yang } \\
\text { memberikan } \\
\text { persetujuan } \\
\text { tertulis atau lisan } \\
\text { secara sukarela } \\
\text { untuk } \\
\text { berpartisipasi }\end{array}$ & $\begin{array}{l}\text { kualitatif } \\
\text { dengan studi } \\
\text { fenomenologis }\end{array}$ & $\begin{array}{l}\text { Dukungan sosial } \\
\text { berupa } \\
\text { dukungan } \\
\text { emosional, } \\
\text { dukungan } \\
\text { informasi, dan } \\
\text { dukungan } \\
\text { finansial yang } \\
\text { diberikan oleh } \\
\text { pasangan, } \\
\text { keluarga inti dan } \\
\text { teman }\end{array}$ \\
\hline $\begin{array}{l}\text { Carr TL, } \\
\text { Cochran D. } \\
(2019)[9]\end{array}$ & $\begin{array}{l}\text { Exploring } \\
\text { women's } \\
\text { support needs } \\
\text { after breast } \\
\text { reconstruction } \\
\text { surgery }\end{array}$ & $\begin{array}{lr}\text { Identifikasi } & \\
\text { kebutuhan } & \text { pasien } \\
\text { setelah } & \text { operasi } \\
\text { payudara } & \end{array}$ & $\begin{array}{l}\text { Pasien kanker } \\
\text { payudara, telah } \\
\text { menyelesaikan } \\
\text { Breast } \\
\text { Reconstruction } \\
\text { (BR) dan dapat } \\
\text { berbahasa Inggris. }\end{array}$ & $\begin{array}{l}\text { desain studi } \\
\text { retrospektif, } \\
\text { wawancara } \\
\text { semi- } \\
\text { terstruktur }\end{array}$ & $\begin{array}{lr}\text { Dukungan } & \text { sosial } \\
\text { diperoleh } & \text { dari } \\
\text { keluarga } & \text { inti } \\
\text { berupa } & \\
\text { dukungan } & \\
\text { emosional, } & \\
\text { dukungan } & \\
\text { finansial, } & \text { dan } \\
\text { dukungan } & \\
\text { informasi. } & \\
\end{array}$ \\
\hline $\begin{array}{l}\text { Ginter AC, } \\
\text { Braun B. } \\
(2019)[12]\end{array}$ & $\begin{array}{l}\text { Social support } \\
\text { needs of breast } \\
\text { cancer patients } \\
\text { without } \\
\text { partners }\end{array}$ & \begin{tabular}{l}
\multicolumn{3}{l}{ Mengidentifikasi } \\
wanita tanpa \\
pasangan dalam \\
memenuhi \\
dukungan sosial \\
selama diagnosis \\
kanker payudara
\end{tabular} & $\begin{array}{lr}\text { wanita, di } & \text { atas } 18 \\
\text { tahun, dirawat } & \text { darena } \\
\text { kanker } \\
\text { payudara } & \text { dalam } \\
\text { lima } & \text { tahun } \\
\text { terakhir, dan } & \text { dasih lajang pada } \\
\text { saat diagnosis dan } \\
\text { pengobatan }\end{array}$ & $\begin{array}{l}\text { Kualitatif } \\
\text { dengan } \\
\text { wawancara } \\
\text { mendalam } \\
\text { kolektif }\end{array}$ & $\begin{array}{l}\text { Dukungan yang } \\
\text { diberikan oleh } \\
\text { keluarga dan } \\
\text { teman-teman } \\
\text { mengambil } \\
\text { bagian dalam } \\
\text { membahas } \\
\text { masalah pribadi } \\
\text { dan }\end{array}$ \\
\hline
\end{tabular}




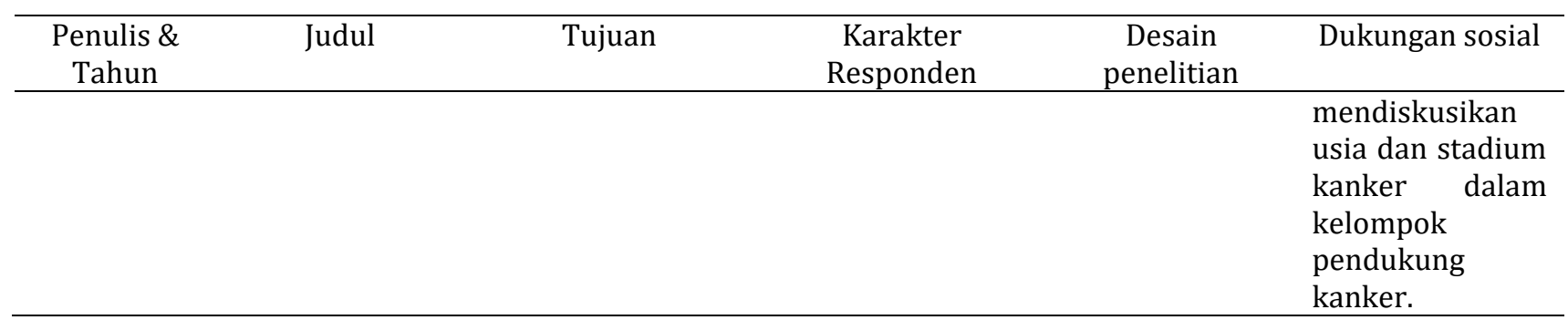

Tabel 2

Dukungan sosial yang diterima wanita dengan kanker payudara

\begin{tabular}{|c|c|c|}
\hline Sumber & Hasil & Tema \\
\hline Burton et al., 2015 [14] & Membantu memberikan keputusan & Dukungan keluarga \\
\hline Paladino et al., 2019 [13] & Keluarga membantu aktivitas & \\
\hline \multirow[t]{2}{*}{ Ginter et al., 2019 [12] } & Mendengarkan keluhan & \\
\hline & Mendiskusikan kondisi pasien & \\
\hline \multirow[t]{3}{*}{ Adam et al., 2020 [15] } & Keluarga membantu keuangan & Dukungan keuangan \\
\hline & Anaknya membantu mencari uang & \\
\hline & Pasangan menyiapkan keuangan & \\
\hline Carr et al., 2019 [9] & Keluarga membantu keuangan & \\
\hline Tompkins et al., 2016 [10] & Menggali perasaan pasien & Dukungan emosional \\
\hline \multirow[t]{2}{*}{ Paladino et al., 2019 [13] } & Keluarga selalu menemani & \\
\hline & Anak selalu membuat tersenyum & \\
\hline \multirow[t]{3}{*}{ Adam et al., 2020 [15] } & Keluarga dan teman menjenguk & \\
\hline & Anak membuat hati dan diri tenang & \\
\hline & Pasangan selalu menenangkan & \\
\hline \multirow[t]{2}{*}{ Carr et al., 2019 [9] } & Keluarga selalu ada & \\
\hline & Keluarga menjadi tempat bercerita & \\
\hline Burton et al., 2015 [14] & Mencari informasi tindakan & Dukungan informasi \\
\hline Tompkins et al., 2016 [10] & Komunikasi dengan breast cancer nurse (BCN) & \\
\hline Paladino et al., 2019 [13] & Mencarikan informasi tindakan & \\
\hline \multirow[t]{3}{*}{ Adam et al., 2020 [15] } & Informasi dari tenaga Kesehatan & \\
\hline & Informasi penyakit kanker payudara & \\
\hline & Dokter menjelaskan kondisi pasien & \\
\hline Carr et al., 2019 [9] & Infromasi dari tenaga kesehatan & \\
\hline Ginter et al., 2019 [12] & Informasi dari komunitas kanker payudara & \\
\hline \multirow[t]{2}{*}{ Ginter et al., 2019 [12] } & Mencari komunitas kanker payudara & Dukungan lain \\
\hline & Mengikuti kegiatan komunitas kanker payudara & \\
\hline
\end{tabular}

\section{Dukungan keluarga}

Sebagian besar wanita penderita kanker payudara mengalami efek negatif, antara lain tidak menerima, khawatir, bahkan takut dengan kondisinya. Kondisi ini membutuhkan keputusan yang harus diambil bersama antara pasien, keluarga, dan profesional kesehatan [9,10,12-15]. Informasi yang jelas, ringkas, dan disesuaikan dengan kondisi yang ada, serta mudah digunakan akan lebih membantu pasien bahkan keluarga untuk mendapatkan informasi yang mereka butuhkan. Dukungan keluarga bahkan tenaga kesehatan sangat dibutuhkan oleh pasien dengan kondisinya saat ini [15].

\section{Dukungan Instrumental}

Kebutuhan selama pengobatan kanker payudara adalah dukungan instrumental yang berupa dukungan finansial. Kebutuhan akan dukungan ini didapat dari pasangan, keluarga, bahkan lingkungan $[9,15]$.

\section{Dukungan respon emosional}

Dukungan yang diperoleh berupa dukungan emosional bagi wanita penderita kanker payudara. Hal terpenting yang ditemukan adalah dukungan pasangan dan keluarga dapat meningkatkan rasa percaya diri pasien $[9,10,13,15]$. 


\section{Dukungan untuk menemukan dan mengakses informasi, berkomunikasi dengan profesional kesehatan}

Keluarga dan teman adalah sumber informasi utama, mulai dari terdiagnosis kanker payudara hingga proses pengobatan. Kebutuhan yang perlu dipenuhi adalah kebutuhan akan informasi tentang kanker dan pelayanan kesehatan yang berkualitas, serta berbagai kendala dalam memperoleh pelayanan kesehatan, dan berbagai perubahan yang terjadi dalam keluarga 9,10,13-15. Kebutuhan ini ditujukan ke berbagai tingkat oleh penyedia layanan kesehatan, anggota keluarga, dan wanita lain yang telah menjalani perawatan kanker payudara $[9,13]$.

\section{Dukungan untuk memenuhi kebutuhan yang tidak terpenuhi}

Wanita dengan kanker payudara membutuhkan dukungan sosial yang tepat dari orang yang mereka cintai dan memperluas jaringan sosial setelah didiagnosis. Banyak wanita dengan kanker payudara tidak mendapatkan dukungan yang mereka butuhkan dari teman dan bahkan keluarga, membatasi individu. Selain itu, penelitian ini menyimpulkan bahwa perlu adanya dukungan dari komunitas wanita penderita kanker payudara untuk meningkatkan semangat dan pemenuhan kebutuhan emosionalnya $[10,15]$.

\section{PEMBAHASAN}

Hasil penelitian ini sesuai dengan literatur yang menunjukkan adanya pemahaman tentang dukungan bagi wanita yang menjalani pengobatan kanker payudara untuk memenuhi kebutuhannya. Wanita yang menjalani perawatan membutuhkan dukungan yang lebih besar dan lebih mungkin untuk menerimanya. Tinjauan ini menunjukkan bahwa individu yang menjalani pengobatan lebih banyak mengalami masalah yang berkaitan dengan masalah psikologis, emosional, sosial, dan seksual dan membutuhkan lebih banyak dukungan untuk mengatasinya [14].

Dukungan emosional dapat mempengaruhi keputusan yang dibuat tentang kepatuhan terhadap pengobatan [9]. Hal ini sejalan dengan penelitian yang melaporkan bahwa dukungan emosional dapat mempengaruhi dan/atau memfasilitasi keputusan mengenai kepatuhan dalam pengobatan, perawatan, dan setelahnya [8]. Studi lain menunjukkan bahwa ada sumber ketidaknyamanan pada pasien bahkan pasangan karena perubahan peran yang dipaksakan karena penyakit yang mereka alami [15]. Hal ini mengakibatkan dukungan yang diberikan tidak lagi menjadi faktor pendukung dan pelindung dalam kondisinya. Belum ditemukan penelitian yang membahas hal-hal yang dapat mengatasi kurangnya keseimbangan antara pasangan dalam menghadapi kanker payudara [16]. Meskipun pasien menghadapi stresor, sangat penting jika diberikan dukungan dari pasangan, dan dapat menguntungkan pasangan itu sendiri [10]. Hubungan sehari-hari antara pasangan dapat bermanfaat bagi kesejahteraan pasien dan memberikan rasa penerimaan dan dukungan timbal balik.

Wanita dengan kanker payudara merasa bahwa mereka mendapatkan lebih sedikit dukungan sosial dari waktu ke waktu. Beberapa melaporkan bahwa ketidak seimbangan dirasakan ketika dukungan yang diminta tidak diberikan atau ketika dukungan yang diberikan tidak diinginkan [17]. Seseorang harus dapat memperhitungkan bahwa persepsi dukungan sosial dapat dipengaruhi oleh faktor-faktor kepribadian serta keadaan psikologis seseorang [10].

Wanita menerima tingkat dukungan yang tinggi tetapi dapat menurun seiring waktu [8]. Pasien yang mengalami tekanan psikologis yang lebih besar akan merasakan dukungan sebagai tanda kecacatan atau hilangnya kebutuhan akan tingkat kemandirian. Penurunan dukungan yang 
dirasakan ini dapat dipengaruhi oleh ketersediaan dukungan yang diberikan atau kualitas dukungan [18]. Menurunnya dukungan yang diberikan oleh keluarga, teman, dan orang lain dapat dikaitkan dengan ketidaksesuaian antara kebutuhan pasien dan dukungan yang diberikan. Hal ini dapat terjadi bila ada komunikasi yang kurang jelas antara pemberi dan penerima dukungan, yang akan berakibat pada menurunnya informasi tentang pasien [10].

Dukungan selama pengobatan terdiri dari keseimbangan kompleks antara keluarga, pasangan, kesejahteraan sosial, penyesuaian psikososial, dan kualitas hidup [14]. Keberhasilan pengobatan tidak hanya ditentukan oleh kesembuhan penyakitnya tetapi bagaimana pasien memandang kualitas hidupnya, salah satunya adalah dukungan sosial.

\section{SIMPULAN}

Dukungan sosial sangat dibutuhkan oleh wanita penderita kanker payudara yang menjalani pengobatan. Memberikan dukungan sosial merupakan bagian dari perawatan integral yang diberikan oleh perawat. Dukungan emosional merupakan hal yang paling penting dan bermanfaat dalam menyesuaikan diri dengan wanita penderita kanker payudara dan akan menjadi kesempatan untuk mengungkapkan perasaan dan mendukung kepatuhan pengobatan. Sumber utama dukungan sosial adalah pasangan, keluarga, dan teman Anda. Mitra penting dalam dukungan emosional dan sumber utama dukungan instrumental.

\section{UCAPAN TERIMAKASIH}

Terima kasih kepada semua pihak yang telah mendukung dalam penulisan literatur ini.

\section{REFERENSI}

[1] Iddrisu M, Aziato L, Dedey F. Psychological and physical effects of breast cancer diagnosis and treatment on young Ghanaian women: a qualitative study 2020:1-9.

[2] Javid SH, Lawrence SO, Lavallee DC. Prioritizing Patient-Reported Outcomes in Breast Cancer Surgery Quality Improvement 2013. https://doi.org/10.1111/tbj.12707.

[3] Globocan. Number of new cases in 2020, both sexes, all ages. WHO 2020;419:1-2.

[4] Globocan. Number of new cases in 2020, both sexes, all ages. WHO 2021;858:2020-1.

[5] Timman R, Gopie JP, Brinkman JN, Kleijne A, Seynaeve C, Menke-pluymers MBE, et al. Most women recover from psychological distress after postoperative complications following implant or DIEP flap breast reconstruction : A prospective long-term follow-up study 2017:112.

[6] Björkman B, Lund I, Arnér S, Hydén L. The meaning and consequences of amputation and mastectomy from the perspective of pain and suffering. Scand J Pain 2016:1-8. https://doi.org/10.1016/j.sjpain.2016.09.012.

[7] Grogan S, Mechan J. Body image after mastectomy: A thematic analysis of younger women ' s written accounts 2016. https://doi.org/10.1177/1359105316630137.

[8] Drageset S, Lindstrøm TC, Giske T, Underlid K. Being in suspense: women' $\mathrm{S}$ experiences awaiting breast cancer surgery 2011. https://doi.org/10.1111/j.13652648.2011.05638.x.

[9] Carr TL, Cochran D. Exploring Women ' s Support Needs After 2019;42:1-9. https://doi.org/10.1097/NCC.0000000000000 600.

[10] Tompkins C, Scanlon K, Scott E, Ream E, Harding S, Armes J. Survivorship care and support following treatment for breast cancer: A multiethnic comparative qualitative study of women's experiences. BMC Health Serv Res 2016;16:5-13.

https://doi.org/10.1186/s12913-016-1625-X.

[11] Speller B, Sissons A, Daly C, Facey M, Kennedy E, Metcalfe $\mathrm{K}$, et al. An evaluation of oncofertility decision support resources among breast cancer patients and health care providers. BMC Health Serv Res 2019;19:1-12. https://doi.org/10.1186/s12913-019-3901-z.

[12] Ginter AC, Braun B. Social support needs of breast cancer patients without partners. J Soc Pers Relat 2019;36:43-62. https://doi.org/10.1177/0265407517718390.

[13] Paladino AJ, Anderson JN, Graff JC, Krukowski $\mathrm{RA}$, Blue $\mathrm{R}$, Jones $\mathrm{TN}$, et al. A qualitative exploration of race-based differences in social 
support needs of diverse women with breast cancer on adjuvant therapy. Psychooncology 2019;28:570-6.

https://doi.org/10.1002/pon.4979.

[14] Burton M, Collins KA, Lifford KJ, Brain K, Wyld $\mathrm{L}$, Caldon $\mathrm{L}$, et al. The information and decision support needs of older women ( $>75 \mathrm{yrs}$ ) facing treatment choices for breast cancer: A qualitative study. Psychooncology 2015;24:878-84.

https://doi.org/10.1002/pon.3735.

[15] Adam A, Koranteng F. Availability, accessibility, and impact of social support on breast cancer treatment among breast cancer patients in Kumasi, Ghana: A qualitative study. PLoS One 2020;15:1-15.

https://doi.org/10.1371/journal.pone.023169 1.

[16] Mackenzie CR. Breast cancer survivors' experiences of partner support and physical activity participation. Psychooncology
2015;24:1197-203.

https://doi.org/10.1002/pon.3808.

[17] Probst H, Rosbottom K, Crank H, Stanton A, Reed $\mathrm{H}$. The patient experience of radiotherapy for breast cancer: A qualitative investigation as part of the SuPPORT 4 All study. Radiography 2021;27:352-9.

https://doi.org/10.1016/j.radi.2020.09.011.

[18] Dumrongpanapakorn P, Liamputtong P. Social support and coping means: The lived experiences of Northeastern Thai women with breast cancer. Health Promot Int 2017;32:76877. https://doi.org/10.1093/heapro/dav023.

[19] Remmers H, Holtgräwe M, Pinkert C. Stress and nursing care needs of women with breast cancer during primary treatment: A qualitative study. Eur J Oncol Nurs 2010;14:11-6. https://doi.org/10.1016/j.ejon.2009.07.002. 